and 248 (85\%) were in LDA according to LLDAS and SLE-DAS LDA, respectively. There was no statistically significant difference between LLDAS and SLE-DAS LDA $(p=0.581$ regarding the identification of patients in LDA. Agreement between these two sets of criteria was almost perfect $(k=0.831$, $\mathrm{p}<0.01)$.

There were 13 discordant cases, fulfilling only the SLE-DAS LDA $(n=8)$ or the LLDAS $(n=5)$, and their manifestations of disease activity (excluding serologic features) are summarized in table 1.

Patients fulfilling only SLE-DAS LDA

\begin{tabular}{|c|c|c|c|c|c|}
\hline $\begin{array}{l}\text { Number } \\
\text { of cases }\end{array}$ & $\begin{array}{c}\text { PGA } \\
\text { (range) }\end{array}$ & $\begin{array}{c}\text { Active clinical } \\
\text { manifestations (range) }\end{array}$ & $\begin{array}{l}\text { SLEDAI-2K } \\
\text { (range) }\end{array}$ & $\begin{array}{c}\text { SLE-DAS } \\
\text { (range) }\end{array}$ & $\begin{array}{l}\text { Prednisolone } \\
\text { (range, } \mathrm{mg} / \text { day) }\end{array}$ \\
\hline 6 & $0.1-0.2$ & $\begin{array}{l}\text { Leukopenia } \\
2.2-2.7 \times 10^{\wedge} 9 / \mathrm{L}\end{array}$ & $1-3$ & $1.46-3.03$ & $0-2.5$ \\
\hline 2 & $0.2-0.3$ & $\begin{array}{c}\text { Thrombocytopenia } \\
71-96 \times 10^{\wedge} 9 / L\end{array}$ & $1-3$ & $1.97-2.86$ & $0-5$ \\
\hline
\end{tabular}

Patients fulfilling only LLDAS

\begin{tabular}{|c|c|c|c|c|c|}
\hline $\begin{array}{l}\text { Number } \\
\text { of cases }\end{array}$ & $\begin{array}{l}\text { PGA } \\
\text { (range) }\end{array}$ & $\begin{array}{c}\text { Active clinical } \\
\text { manifestations (range) }\end{array}$ & $\begin{array}{l}\text { SLEDAI-2K } \\
\text { (range) }\end{array}$ & $\begin{array}{c}\text { SLE-DAS } \\
\text { (range) }\end{array}$ & $\begin{array}{l}\text { Prednisolone } \\
\text { (range, mg/day) }\end{array}$ \\
\hline 2 & $0.2-0.4$ & $\begin{array}{l}\text { Arthritis (2-4/28 swollen } \\
\text { joints) }\end{array}$ & 4 & $4,41-5.31$ & $0-5$ \\
\hline 1 & 0.5 & $\begin{array}{l}\text { Panniculitis (face and } \\
\text { torso) }\end{array}$ & 3 & 5,53 & 0 \\
\hline 1 & 0.1 & Generalized rash & 4 & 5,01 & 5 \\
\hline 1 & 0.4 & $\begin{array}{l}\text { Leukopenia } 2.1 \times 10^{\wedge} 9 / \mathrm{L} \\
\text { Thrombocytopenia } \\
62 \times 10^{\wedge} 9 / \mathrm{L}\end{array}$ & 2 & 4,99 & 0 \\
\hline
\end{tabular}

Conclusion: A LDA state, by either definition, was achieved by most patients in this real-life setting. LLDAS and SLE-DAS LDA identify almost exactly the same population. The SLE-DAS LDA definition is easier to apply and hence might be the optimal definition for use in daily clinical practice.

References:

[1] Franklyn K, Lau CS, Navarra SV, et al. Definition and initial validation of a Lupus Low Disease Activity State (LLDAS). Ann Rheum Dis 2016; 75 : $1615-21$.

[2] Jesus D, Matos A, Henriques C, et al. Derivation and validation of the SLE Disease Activity Score (SLE-DAS): a new SLE continuous measure with high sensitivity for changes in disease activity. Ann Rheum Dis 2019; 78 : 365-71.

[3] Jesus D, Matos A, Henriques C, et al. The SLE Disease Activity Score (SLEDAS) enables accurate definitions of SLE remission and LDA as achievable targets in disease management. Ann Rheum Dis 2019; 78: 411-2.

Disclosure of Interests: Helena Assunção: None declared, Diogo Jesus: None declared, José Antonio P. da Silva Grant/research support from: Pfizer, Abbvie, Consultant of: Pfizer, AbbVie, Roche, Lilly, Novartis, Luís Inês: None declared DOI: 10.1136/annrheumdis-2020-eular.1744

\section{OP0093 FREQUENCIES AND PREDICTORS OF THE LUPUS LOW DISEASE ACTIVITY STATE AND REMISSION IN TREATMENT-NAÏVE PATIENTS WITH SYSTEMIC LUPUS ERYTHEMATOSUS -- A REAL-WORLD COHORT STUDY}

D. Gao ${ }^{1}$, Y. Hao ${ }^{1}$, L. Mu ${ }^{1}$, W. Xie ${ }^{1}$, X. Sun ${ }^{1}$, Y. Fan ${ }^{1}$, L. Ji ${ }^{1}$, Z. Zhang ${ }^{1} .{ }^{1}$ Peking University First Hospital, Rheumatology and Clinical Immunology Department, Beijing, China

Background: After the introduction of treat-to-target strategy in systemic lupus erythematosus (SLE), Lupus Low Disease Activity State (LLDAS) and definitions of remission in SLE (DORIS) were developed and validated. Several studies had demonstrated that the achievement and maintenance of LLDAS or DORIS was associated with good prognosis.

Objectives: To evaluate the attainability of LLDAS and DORIS in a treatment-naïve cohort of SLE.

Methods: LDAS5 was defined as LLDAS with a prednisone dose $\leq 5 \mathrm{mg} / \mathrm{d}$. There were 4 definitions in DORIS: clinical remission on treatment (RONT), complete RONT, clinical remission off treatment (ROFT) and complete ROFT. The treatment-naïve patients from Peking University First Hospital SLE cohort were enrolled. The time to each state and their annual cumulative probabilities were estimated by Kaplan-Meier approach. The frequencies of patients who achieved each component of LLDAS or DORIS during follow-up were determined.

Results: A total of 218 treatment-naïve patients were included, with a median follow-up of 4.48 years. Respectively, 190 (87.2\%), 160 (73.4\%), 148 (67.9\%), 94 (43.1\%), $23(10.6 \%)$ and $18(8.3 \%)$ patients achieved LLDAS, LLDAS5, clinical RONT, complete RONT, clinical ROFT and complete ROFT at least once during the follow-up time. The median time to LLDAS, LLDAS5, clinical RONT and complete RONT were 1.4, 2.3, 2.6 and 4.7 years, respectively.

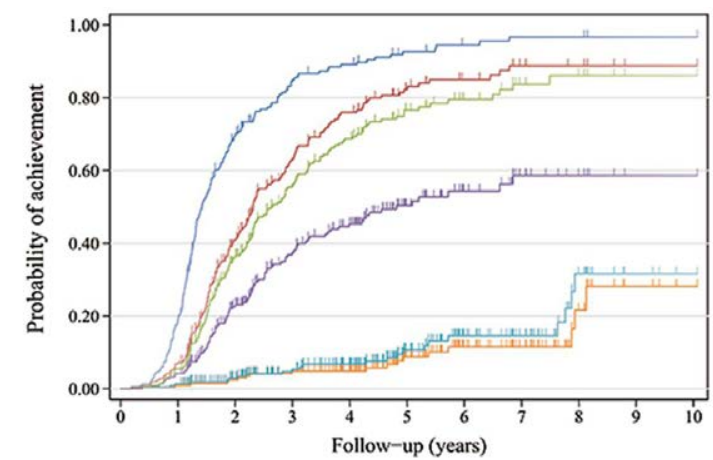

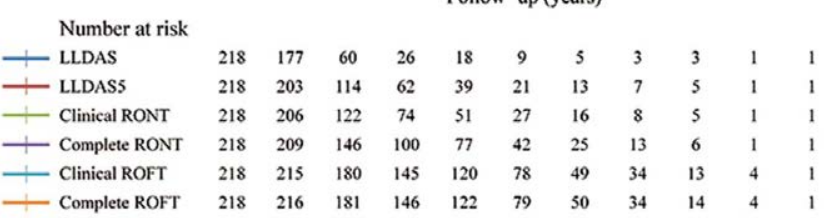

Figure 1 Kaplan-Meier curves of time to LLDAS, LLDAS5 and each state of DORIS

Table 1. Frequencies, time to achieve and annual cumulative probabilities of each state by Kaplan-Meier approach

\begin{tabular}{|c|c|c|c|c|c|c|c|}
\hline \multirow[t]{2}{*}{ States } & \multirow{2}{*}{$\begin{array}{c}\text { Achieved } \\
\text { patients } \\
\text { Number (\%) }\end{array}$} & \multirow{2}{*}{$\begin{array}{l}\text { Time to } \\
\text { achieve } \\
\text { (years) }\end{array}$} & \multicolumn{5}{|c|}{ Cumulative probabilities of achievement (\%) } \\
\hline & & & Year 1 & Year 2 & Year 3 & Year 4 & Year 5 \\
\hline LLDAS & $190(87.2)$ & 1.4 & 18.8 & 69.7 & 86.7 & 89.1 & 92.6 \\
\hline LLDAS5 & $160(73.4)$ & 2.3 & 6.9 & 40.7 & 63.3 & 76.0 & 82.3 \\
\hline Clinical RONT & $148(67.9)$ & 2.6 & 5.5 & 36.1 & 56.1 & 68.8 & 76.6 \\
\hline Complete RONT & $94(43.1)$ & 4.7 & 4.1 & 22.6 & 37.5 & 45.3 & 50.4 \\
\hline Clinical ROFT & $23(10.6)$ & NA & 1.4 & 2.9 & 5.4 & 6.7 & 10.6 \\
\hline Complete ROFT & $18(8.3)$ & NA & 0.9 & 2.5 & 4.8 & 4.8 & 8.8 \\
\hline
\end{tabular}

Table 2. Patients who achieved each component of LLDAS or DORIS during follow-up

\begin{tabular}{lc}
\hline Components & Number (\%) \\
\hline $\begin{array}{l}\text { SLEDAI-2K } \leq 4, \text { with no activity in major organ systems (renal, central } \\
\quad \text { nervous system, cardiopulmonary, vasculitis, fever), and no haemolytic }\end{array}$ & $213(97.7)$ \\
$\quad$ anaemia or gastrointestinal active & \\
Clinical SLEDAl-2K $=0$ & $210(96.3)$ \\
PGA $\leq 1$ & $217(99.5)$ \\
PGA $<0.5$ & $199(91.3)$ \\
Serology (anti-dsDNA and complement) negative & $148(67.9)$ \\
Prednisone dose $\leq 7.5 \mathrm{mg} /$ day & $201(92.2)$ \\
Prednisone dose $\leq 5 \mathrm{mg} /$ day & $171(78.4)$ \\
No prednisone dose & $40(18.3)$ \\
No prednisone dose and Immunosuppressants & $32(14.7)$ \\
\hline
\end{tabular}

Conclusion: Our data confirmed that LLDAS is an attainable early treatment target for SLE. Though with more difficulty, RONT can be achieved in two-thirds of our patients. ROFT may not be an ideal treatment target at present as it is only attained in few patients.

References:

[1] Franklyn, K. et al. Ann Rheum Dis. 2016 Sep;75(9):1615-21.

[2] van Vollenhoven, R. et al. Ann Rheum Dis. 2017 Mar;76(3):554-561.

Disclosure of Interests: None declared

DOI: 10.1136/annrheumdis-2020-eular.3041 